\title{
The English Influence on Cantonese Vocabulary
}

\author{
Youbin Zhao \\ School of Translation Studies \\ Jinan University \\ Guangdong, China \\ e-mail:youbinz@jnu.edu.cn
}

\begin{abstract}
Cantonese is one kind of Chinese dialects used by more than 70 million people and it's the native dialect used by the biggest population in the world. Being one of the most absorbing language, the formation of Cantonese vocabulary is very complex. This paper introduces the representation of English influence on Cantonese vocabulary and the causes and the inspiration which can help people to know Cantonese in a comprehensive way.
\end{abstract}

Keywords-Cantonese; loan words; English; influence; causes; inspiration

\section{INTRODUCTION}

There are lots of loan words in Cantonese with the pursuit of fashion for the last 20 years. For example, cookies(曲奇), bus(巴士),radar(雷达) and so on. This phenomenon is particular acute in coastal areas. There are many English loan words in Cantonese, most of which are innate in Cantonese and were popular long before. Nowadays, these words in Cantonese are applied by us without awareness of the English loan words. And with the absorbing of English, more and more people get used to using these words in their daily life in Guangdong. Mr. Ji Xianlin says that culture has its features and once it is produced, it would pass on not only in its nation but also in other nations, which produce cultural exchanges. This indicates that English has an significant influence on Cantonese which has enriched Cantonese and is the best model of cultural exchanges. There are many manifestations of English influence on Cantonese vocabulary we can see in our daily life as a local person. Moreover, the constitution and the specific features of these influences in vocabulary will be analyzed in this thesis. And you would like to know the historical and realistic reasons for the borrowing of English words in Cantonese. Last but not least, the inspiration from English influence on Cantonese Vocabulary is to be talked about.

\section{HiSTORIC INFLUENCE OF ENGLISH ON CANTONESE VOCABULARY}

English has a remarkable influence on Cantonese. Historical reason takes an important role in its influence and social reasons come second. There is no doubt that language developed with history. And history has a significant influence on Cantonese for a long time. According to historical records, the United States sent a merchant fleet to China for the first time in 1637, Chinese has absorbed words generally concerning science and technology to fill in the lexical gaps: 氨(ammonia), 铵(ammonium), 苯(benzene), 菲林(film), 拷贝 (copy), 珂罗版 (collotype),X 光 (X-ray), CD(computerized tomography), 试管贞儿(test-tube-baby), 克隆(clone), 雷达 (radar), DDT(dichloro-dipheny-trichlorethae) and 多米诺效 应(domino effect), to cite just a few.

As a result of cultural and language contact, loan words usually introduce the social topics in which the donor language and culture take the leading role. A contrast of the different topics Chinese and English loan words belonging to, or the semantic areas of loan words, as is assumed by Spir(1921:207), Gray(1939:130) and Bynon(1977:216), reflects the nature of contact between Chinese and English speakers.

Toda, 酷(cool), 丁克(dink) have become part of their everyday speech,. And when hearing 开派对(have a party), 麦当劳(MacDonald) and 迪斯科(disco),no one will feel puzzled.

The reform and opening policy also influenced people's attitude toward words from the West. During the ten years of Cultural Revolution anything associated with the West was severely criticized as capitalism and counter-revolutionary or at least as having a servile attitude to foreign things. People had sharp vigilance to avoid anything Western, including words. So 酒吧(bar) a once popular term in big cities before 1949 , had been largely reduced in public. It was only since the practice of reform and opening to the outside world after 1978 that 酒吧 (bar)revived to mean the common bar.

The entry of China into the WTO in 2001, Beijing's successful bidding for Olympic Games 2008, and the rapid development of economic and cultural cooperation between China and the outside world will undoubtedly improve the communication between people of China and other countries. Needless to say, more and more loan words will enter Chinese language to enrich its vocabulary.

English and Cantonese are typologically distinct languages but this in no way impedes mutual borrowing. English loan words are documented in the first English-Cantonese, Cantonese-English dictionary published in 1828 .

What's more, historical contact between English and Cantonese began in the late 17th century when British traders came to Canton to buy Chinese tea and porcelain. English has 
great influence on Cantonese. The most important is the historical reasons and then come to the social reasons. Language comes from history, and the influence of English on Cantonese has a long history. According to historical records, the United State sent a merchant fleet to China for the first time in 1637, and then set up the office of Dutch East India Company. From then on, the United States has more frequent contacts with China. The opium war was the confrontational contact, but as long as there is contact, there are bound to be the effect of language. After Nanking Treaty was just concluded and signed in 1842, the scholar "Weiyuan" brought out his book for "anger and grumbling" ,commissioned by Lin Zexu. There are many English loan words in this book.

The link between China's Cantonese-speaking region and English is strong, owing to the British presence in Hong Kong until 1997. There are a number of ways that a native Cantonese speaker can learn English, although there is no substitute for practice. Although learning the basics can best be achieved in a class, there is only so far that you can go with class-based learning. Immersing yourself in an English-speaking culture will quickly improve your language skills.

\section{THE MANIFESTATION OF ENGLISH INFLUENCE ON CANTONESE VOCABULARY}

Loan words are an important sociolinguistic phenomenon. English loan words are prominent in Cantonese. With the development of society and language, social change must bring to language changes. And there are many new words with the development of society and the cultural communication between foreign countries and our nation which has made new things, new concepts and latest technology rush to domestic market. As a kind of Chinese dialects, Cantonese has absorbed lots of English loan words. Since our reform and opening to the world, Cantonese has become the most competitive in the Chinese dialects. And Cantonese absorbed lots of English loan words. There are different kinds of English loan words that influence Cantonese vocabulary.

First, food, clothing shelter and transportation and daily expression:

Jacket(夹克), nylon(尼龙), coffee(咖啡), chocolate(巧克 力), brandy(白兰地), sandwich(三明治), pudding(布 丁), sofa(沙发), bus( 巴士), taxi(的士), mousse( 摩丝), model(模特), romantic(罗曼蒂克), humor(幽默), show(秀), $\operatorname{cool}($ 酷), disco(迪斯科), Beer(啤酒), jar(扎), pump(泉), T-shirt( $\mathrm{T}$ 恤衫), bikinis(比基尼), cookies(曲奇), cracker(克力 架), jelly(者厘), whisky(威士忌), McDonald(麦当劳), Kentucky Fried Chicken(肯德基), Pizza Hut(必胜客), Coca-cola(可口可乐), shampoo(香波), carcoa(卡曲), cassette(卡带),pie(派), card(卡), mango(芒果), Sprite(雪碧), lemon(柠檬), vitamin(维他命), hippy(嬉皮士), size(晒士), case(畸士), boss(波士), mammy(妈咪), Daddy(爹地), tip(贴 士 ), modern(摩登), motor(摩托), cent(仙), tart(蛋挞), cheese(芝士), film(菲林), $\operatorname{mark}($ 唛), ap(蛤帽), guart(骨), stamp(士担), pair(pair 牌), number(霖巴), lift(笠), change(畅), ball(波), sorry(梳利), line(冷), spanner(士吧拿), sanna(桑拿
浴), pose(甫士), sir(啊 sir), face(飞士), order(奥打), call(柯), class(卡士), jelly(果冻), file(快劳), shortcake(雪克)

Second, sports, art \& literature, technology \& science and medicine:

Marathon( 马拉松),Saxhorns( 萨克 斯 ), guitar( 吉 他),Hollywood(好莱坞), totem( 图腾), tank(坦克), radar(雷 达), clone(克隆), logic(逻辑), email(伊妹儿), aspirin(阿司匹 林),penicillin(盘尼西林),bungee jumping(蹦极),gene(基 因),faseline(凡士林)

Third, some social phenomenon:

$\operatorname{Dink}($ 丁克),punk(朋克), hacker(黑客)

Forth, foreign brands:

Addidas( 阿迪达斯),nike( 耐克),Marlboro( 万宝 路 ),Ferrari( 法拉利 ),Cadillac( 卡迪拉克),Sony( 索 尼),Nokia(诺基亚),Prada(普拉达)

Fifth, names of foreign countries, places,buildings, rivers and mountains:

Ireland( 爱尔兰),Paris( 巴黎),Mississippi( 密西西 比,Afghan(阿富汗),Andes(安第斯山脉),Nile(尼罗河,Pisa(比 萨斜塔),New Zealand(纽西兰),Singapo(新加波),

\section{Sixth, names of foreign people and foreign literature:}

Einstein( 爱因斯坦),Mozart( 莫扎特),Van Gogh( 梵 高),Mark Twain(马克. 吐温),Don Quixote(堂吉诃德),Jane Eyer(简爱),Mickey Mouse(米奇老鼠)

\section{Seventh, Monetary unit:}

Pound(磅),ton(吨), ounce( 盎司, gallon(加仑),France( 法 郎), Mark(马克), Rupee(卢比)

Most of English loan words in Cantonese are still applied nowadays

Cantonese is one of the important Chinese dialects which is used by the people in the southern area. Guangdong is the portal of southern China which included Hong Kong and Macau. And it is the first province to carry out the Opening policy, in addition, Guangdong has taken a significant role in the communication of domestic and foreign countries. In the past 10 years, Guangdong (Pearl River Delta has set up three special economic zones which included Shenzhen, Zhuhai,Shantou. Pear River Delta has developed in a rapid speed. There are foregin trades and communication activities in this area, making Guangdong become a multielement place. As the main language applied in Guangzhou, Shenzhen, Zhuhai and other places in Pearl River Delta, Cantonese become more and more important and necessary in the foreign trades and communication activities between domestic and foreign world. The following factors can provide the reasons why it is important in southern China. First of all,Hong Kong and Guangdong are, regarded as the communication bridge of foreign countries and China, and their people use Cantonese as their mother language in daily life. 


\section{THE SPECIFIC REPRESENTATION OF ENGLISH LOAN WORDS}

Hong Kong and Macau are the cities of communication between east and west. And with the development of economy, they have become the International Trade Center, especially Hong Kong, since the 1960s. Guangdong is the province which is the neighbor of Hong Kong and Macau, therefore, its' culture has been influenced by Hong Kong and Macau in a large extent, especially in the aspect of daily life and language they use. New words which reflect new things and new concept of the world have rushed to our daily life with the development of the communication of culture and the progress the society has made. The sources of this phenomenon include three main aspects:

(1) created by people

(2) selected in the language itself

(3) loan words

Here I would like to introduce some information about loan words. Sapier once said "language is just like its culture which is hard to be self-sufficient."Communication makes one person who speaks one language contact with the people in the neighboring country or the people who have dominant culture directly or indirectly. Communication can be friendly and antagonistic. It can be carried out in common affairs, trading business and a load or an exchange of mentality of art, science, religion and so on. Edward Sapier, a famous American linguist, wrote down the judgement seventy years ago, which recognized the inevitability of language exchange and lending. The present era, day by day strengthens along with the economical globalization tendency, the lending and exchange of language would be frequent day by day. Hong Kong and Macau are in the intersection of the Chinese and western culture, and it is inevitable to borrow from other languages.

A loanword is also called an external word, and is referred to the word and expression which from other languages, which plays a vital role to enrich and develop a language.

Guangdong is located in the intersection of the Chinese and western culture, so it's inevitable to borrow languages of other nations. Loan words mean foreign words or some language from abroad. There are different ways in the Cantonese absorbing English loan words. For a better understanding in this article, here I would like to explain some concept about English loan words. In the Encyclopedia American, there is one sentence that "The English language has vast debts. In any dictionary some $80 \%$ of the entries are borrowed" which indicated that there were a large number of borrowed words in English. There are both historical and realistic reasons for the borrowing of other languages' words. A loanword (or loan word) is a word borrowed from a donor language and incorporated into a recipient language. By contrast, a calque or loan translation is a related concept where the meaning or idiom is borrowed rather than the lexical item itself. The word loanword is itself a calque of the German Lehnwort, while calque is a loanword from French.
The terms borrow and loanword, although traditional, conflict with the ordinary meaning of those words because nothing is returned to the donor languages. However, note that this metaphor is not isolated to the concept of loan words, but also found in the idiom "to borrow an idea." An additional issue with the term loanword is that it implies that the loaning is limited to one single word as opposed to phrases such as déjà vu, an English loanword from French. While this phrase may be used as one lexical item by English speakers, that is to say, an English speaker would not say only déjà to convey the meaning associated with the full term déjà vu, in the donor language (French), speakers would be aware of the phrase consisting of two words. For simplicity, adopt/adoption or adapt/adaption are used by many linguists, either in parallel to, or in preference to, these words. Some researchers also use the term lexical borrowing.

\section{CONCLUSION}

From the analysis of the above, we can become conscious of the entering and gradual prevalentness of borrowed words in Cantonese are in conformity with the universal law of language development, and they are the consequence of the advancement and development of the whole society. "the stability and order of language are relative while the variation, disorder and innovation are absolute". The variation, development and stability of language, including the absorbing of loan words, are both contrary and uniform together. The language itself has the ability to sift and filtrate, and this kind of internal regulatory function and the effect of mutual restriction among the three basic aspects: vocabulary, gramma and pronunciation, can preserve the substaintial stability of language. Cantonese enriched its own vocabulary immensely by the unceasing absorption of English loan words which is useful for Cantonese. It was the continuous blending of the borrowed words that enriched the Cantonese vocabulary vastly and made English to be a kind of complex language which has become treasure for Chinese in southern. We further embedding of the development of language and the communication of culture, this kind of loan words will be using incessant, and the Cantonese will consequentially reveal the stronger vitality. The integration of loan words has been analyzed according to several aspects: the writing system, the morpho-syntactic structure, word formation processes, semantic feature, and social acceptability. The evidence is clear that many English loan words have been fully integrated into the Cantonese language. More recently borrowed items tend to show fewer of the above features, indicating that the integration process takes time and it is an ongoing one.

\section{REFERENCES}

[1] Bauer, R. (1985) The Expanding Syllabary of Hong Kong Cantonese. C.L.A.O. vol.XIV.1: 99-111.

[2] Kao, D.L. (1971) Structure of the Syllable in Cantonese

[3] Kramsch Claire. Language and Culture[J]. Shanghai Foreign Language Education Press. 2006.(7): 85-89. 